\title{
LITERATURE
}

@

\author{
Paula Wieczorek \\ University of Rzeszów, Poland \\ WIECZOREK1PAULA@GMAIL.COM \\ HTTPS://ORCID.ORG/OOOO-0OO2-7295-8619
}

\section{Plant Life and More-than-human Agency in Zainab Amadahy's Resistance}

\begin{abstract}
For centuries humans have acted as if the environment was passive and as if the agency was related only to human beings. Both Indigenous and non-Indigenous writers, scholars, and artists express the need to narrate tales about the multitudes of the living earth, which can help perceive the Earth as vibrant and living. The following paper discusses Black/Cherokee Zainab Amadahy's speculative fiction novel 2013 Resistance as an example of a story resisting the claim about human beings as the ultimate species. The paper initially scrutinizes the phenomena of "plant blindness" and then explores how Zainab Amadahy illustrates plant life in her book. Unlike in traditional literary depictions of botany, the writer presents tobacco as an active and responsive agent that influences the characters, which, consequently, opposes anthropocentrism. The article also addresses the cultural violence and disregard that has dominated the Western perception of animistic cultures and expresses the need to rethink the theory of animism. This paper draws from posthumanist writings by scholars including Donna Haraway, Bruno Latour, Jane Bennett, and Stacy Alaimo. It also refers to some of the most influential contributions to critical plant studies made by Indigenous thinkers such as Robin Wall Kimmerer's Braiding Sweetgrass (2013).
\end{abstract}

Keywords: Zainab Amadahy, agency, plants, tobacco, posthumanism, animism.

\section{Introduction}

Timothy Clark points out that the Anthropocene is a period in which the environment "ceases being only a passive ground, context and resource for human society and becomes an imponderable agency that must somehow be taken into account, even if we are unsure how" (Clark 2010, 134). For centuries, humans have acted as if the 
environment was passive and as if agency was related only to human beings. Clark points out that the environment can no longer be perceived as something at material or philosophical distance from the human species, but it needs to be viewed as something within which humans are inextricably entangled.

Indigenous scholars Zoe Todd (2016) and D. H. Justice (2018) emphasise the significance of ecological imagination to the empathy needed for respectful, healthy, and sustainable relationships and communities. In her book Staying with the Trouble: Making Kin in the Chthulucene, Donna Haraway also stresses the importance of imagination and the need for telling Gaia stories, i.e. the stories that change the way humans position themselves in the natural environment. In other words, stories should no longer praise human exceptionalism, the Anthropos. As Haraway notices, the Man-making tales of action with only one real actor, who is the hero, the world-maker, tend to defer "the suffering of earth-rotted passivity beyond bearing" $(2016,118)$. Similarly, Indigenous artists express the need to narrate tales where the knowledge of multitudes of the living Earth is not scarce. Contemporary ecocriticism has encouraged artists and writers to create stories that can aid us to perceive the Earth as "a moving, shifting character, full of its vitality in a longer storyline that precedes and exceeds us" (Harris 2017, 180).

The following paper looks at Black/Cherokee writer Zainab Amadahy's Resistance (2013) as an example of a story that opposes anthropocentrism. It resists the claim about human beings as the ultimate species and, instead, discloses a view of plants as responsive and expressive agents. In particular, it explores how tobacco is represented as an active agent that influences the characters. The paper discusses the phenomena of "plant blindness" and, subsequently, examines how tobacco exerts material agency in the novel. Unlike in traditional literary depictions of botany, Amadahy presents tobacco as a living being, thus, challenging the perception of life and nonlife. The paper also addresses the cultural violence and disregard that has dominated the Western perception of animistic cultures and expresses the need to rethink the theory of animism. This paper draws from posthumanist writings by scholars including Donna Haraway, Bruno Latour, Jane Bennett, and Stacy Alaimo. It also refers to some of the most influential contributions to critical plant studies made by Indigenous thinkers such as Robin Wall Kimmerer's Braiding Sweetgrass (2013).

\section{Plant Blindness}

In his book The Cabaret of Plants, writer Richard Mabey points out that plants are often treated as a mere backdrop for human activity and existence: "as the furniture of the planet, necessary, useful, attractive, but 'just there', passively vegetating" (Mabey 2018 , 4). This lack of concern was explained by botanists and environmental educators James H. Wandersee and Elisabeth E. Schussler, who have written about the phenomena named "plant blindness," i.e. the "inability to see or notice plants in one's own 
environment", which results in the "inability to recognise the importance of plants in the biosphere and in human affairs" (Wandersee and Schussler 1999, 82). One of the characteristics of human marginalisation of plants is thinking of them as simply the background for animal life. Francis Halle (2002) explains that this stems from the prevailing zoocentrism or anthropocentrism as well as the fact that human beings do not identify with plants as eagerly as with animals.

Scientists and philosophers have traditionally privileged the study of animals, including the study of human beings. In ancient philosophical thought, there are, however, some theories on plants. Following Empedocles and, presumably, Pythagoras, Plato considered plants to be living beings that differ from animals and possess souls and minds (Skemp 1947). On the other hand, during Greek Neoplatonism, Aristotle tried to dismiss the theories of plants having intelligence and developed the idea of the so-called scala naturae, (also known as the "ladder of nature," or the "great chain of being"), which organised living and non-living things in the natural world. Since Aristotle considered humans to be unique, "political" animals gifted with logos - reason, speech, language, he ranked humans at the top of the hierarchy (Aristotle 1932). Plants were located just above inanimate things and considered to be an imperfect lower form of life, ontologically lacking the characteristics which made animals superior, i.e. intentionality, movement, or the ability to communicate. This worldview remained influential throughout the medieval as well as the early modern periods in Europe as it posited a hierarchical universe where inanimate beings were placed at the lowest level of the scale, followed by plants, animals, humans, angels, and God. Thus, the idea of "the great chain of being" contributed to the separation of humans from nature. Most plants continued to be relegated to the margins of philosophy as less worthy of attention than animals long after the Renaissance. The Aristotelian ranking system was an inspiration for Martin Heidegger, who created a hierarchy of Being by claiming that "the stone is worldless [weltlos]; the animal is poor in world [weltarm]; man is world-forming [weltbildend]" (Heidegger 2001, 177). The favouring of animals over plants continues in contemporary philosophy as well. Works concerning the relationship between humans and animals range from the landmark 1975 book Animal Liberation by Peter Singer to Donna Haraway's When Species Meet (2008) and Cynthia Willett's Interspecies Ethics (2014). The history of the human-plant relationship indicates that plant blindness is deeply ingrained in "cultural-philosophical attitude" (Hall 2011, 9).

Compared to philosophy and science, literature and culture have been more attentive to the plant world, although not without the biases toward and appropriations of the vegetal. In Greek mythology, there are the stories of the dryads, i.e. the nymphs or spirits of trees and woodlands. Plants play critical roles in culture, ranging from Green Man legend and iconography, the Tree of Mercy in the Bible, Odin's Yggdrasil to laughing human-face Jinmenju and fantastic stories of lamb plants. Floriography, or a means of communication through flowers, has long been explored and represented in the Song of Solomon or Shakespeare's Hamlet (1600), as well as the nineteenth-centu- 
ry British drawing rooms. Fiction has been immensely influenced by Charles Darwin's work on plants in the 1870 s, which resulted in the numerous stories of botanical wonders and monster plants. Monica Gagliano notices that poetry and prose in Western literature are likely to represent plants as the backdrop for humans or as a part of the landscape. The mysterious intricacies of plants are often relegated to narrative blind spots in a wide range of literary world (Gagliano, Ryan, and Vieira 2017, x).

In the introduction to Plants in Science Fiction, Katherine E. Bishop points out that this abundance of plants in popular culture and science fiction actually suggests "an acknowledgement that plants have capabilities that we humans neither share nor yet fully comprehend" (Bishop, Higgins, and Maatta 2020, 2). It seems that the first step to understanding plants is to question the way humans perceive them. An American author Robert Hass writes in his 2015 poem "The Problem of Describing Trees" that "There are limits to saying, / In language, what the tree did" (Robert Hass 2005). Arboreal subjects are likely to be seen and described by humans in human terms; we seem to be limited in our ability to see beyond ourselves and tend to anthropomorphise trees instead, i.e. attribute human traits, intentions, emotions, and activities (like dancing, whispering, shivering) to them.

However, as the awareness of the dire ecological state of the planet grows, artists and scholars become more interested in the vegetal world. The studies on plant life, which have been long marginalised, appear to have gained new momentum in recent decades and attempt to comprehend plants in their own terms. More and more writers draw attention to the agency of plants in their stories and present them as living; Zainab Amadahy's Resistance may serve here as an example.

\section{More-than-human agency in Zainab Amadahy's Resistance (2013)}

Zainab Amadahy is an artist of African-American and Cherokee heritage, who has attempted to depart from the Indigenous realism and the traditional representations of the colonial past, and, instead, she turned to speculative fiction to represent the influence of the colonial history on the present situation of Native Americans and depict decolonised visions of the future. Zainab Amadahy's Resistance (2013) is set in Toronto in 2036 when North American cities are bankrupt and ruined due to global warming, the economic crash of 2023 and the flu epidemics of ' 24 and '26, which were caused by a genetically engineered virus. With the spread of flu epidemics, most institutions were closed by the authorities intending to contain the pandemic. Toronto General Hospital was defunded, and the equipment was transferred to the hospitals outside the city. Rural areas began to fill with squatters and the unemployed searching for jobs, food, or a place to settle. Urban gangs were terrorising citizens out of food and supplies, and the poorest could not afford transportation out of the city. This situation seems to illustrate David Wallace-Wells' claim that increased heat dramatically enhances criminal and disruptive behaviours, including assaults, murders, rapes, rob- 
beries, and suicidality (Wallace-Wells 2019, 129, 138). Then, when the government lost control of the situation and corporations started to profit from people's tragedies and natural disasters, activist leaders began to form communities to promote environmental sustainability. One of the novel's main characters, Vicente "Chente" Montoya, puts much effort into developing community gardens. Together with a medical doctor, Tamaya "Tam" Wilson, they established a clinic community that lives on a disputed land coveted by a mining company. Their community relies on both modern (techno-) science and Indigenous knowledge and is founded on the ideas of cooperation and reciprocity rather than rivalry. When Tam asks to describe the communal structure and culture, she responds:

A whole new way of being in this world. Cooperation, compassion, they've been ridiculed and denigrated for centuries in favour of competition, individualism and the profit motive. But we human beings are actually wired for cooperation. We benefit physically, mentally and emotionally from caring and sharing. (Amadahy 2013, 68)

Tam advocates for an Indigenist relational worldview, in which cooperation is valued and any contribution to the community's development is received with gratitude.

The community relies on the teachings of plants and attempts to imitate the way plants collaborate. As Zulie, one of the community members, explains: "It's kind of a really nice teaching about how the plant world cooperates and how their cooperation contributes to our well-being. Something we try to role model in this community" (2013, 47). In her 2013 book, Braiding Sweetgrass, an Indigenous scientist Robin Wall Kimmerer explains the way plants might tell people how to live. She provides an example from Indigenous agriculture concerning the Three Sisters, i.e. the three plants: corn, beans, and squash, which grow together and complement each other in the garden. When the bean sprouts, it wraps its shoots around the corn stems, which later acts as a support for the climbing bean. Meanwhile, the squash grows broad leaves, which help keep moisture and repel weeds. In this way, the three sisters can survive severe winters as they cooperate below ground and above ground. The Three Sisters provide a manifestation of what a community can become when its members share their gifts.

Similarly, the Three Sisters offer a new metaphor for an emerging entanglement between Indigenous knowledge and Western science, which are rooted in the earth. As Kimmerer suggests, corn can be thought of as "traditional ecological knowledge, the physical and spiritual framework that can guide the curious bean of science, which twines like a double helix. The squash creates the ethical habitat for coexistence and mutual flourishing" (Kimmerer 2013, 148). In the fictional Indigenous community in Amadahy's novel, traditional knowledge coexists together with scientific knowledge. The characters resort to both traditional Indigenous healing practices, ceremonies and Western medicine and they attend group psychotherapy which is complemented with yoga classes. Indigenous Elders provide spiritual guidance for the community members, who gather their own food and sustainably produce energy. 
The protagonist, Inez Xicay, is invited to practice medicine in Toronto by Tam. Inez is a nanotechnology researcher of African Latina and Indigenous descendent, who lost her job and project funding due to her abusive former boss. As the mining company prevents Inez from leaving the country, the woman decides to stay for a more extended period and help the victims of riots and assaults. Having been trained in Western academic culture, Inez is a medical researcher who remains sceptical towards treating people using traditional Indigenous knowledge. For her, the animistic or "relational" ontologies found in non-Western, premodern environment challenge modern Western knowledge production. She considers ceremonies and prayers to be simply placebos. At the same time, the community working at Toronto's clinic finds Inez's research on the enhancement of the immune system irrelevant.

Inez undergoes a metamorphosis as a character and, eventually, comes to terms with balancing the sense of individualism with community needs. Her change begins when she receives tobacco from Grandmother Louise. Within many North American Indigenous communities, this gesture marks an ethic of reciprocity, and it embodies an understanding that in pursuit of knowledge, an individual becomes engaged in a co-constituting ethical relationship with other agents (Kovach 2009). An ethic of reciprocity with non-human agents means that the person seeking insight into any part of the environment is not entitled to that knowledge. Instead, they need to consider what they are giving in return to the agents with whom they form a network of relations. What is provided reciprocally in the process of inquiry may involve helping to fulfil purposes other than one's own or symbolic gestures that recognise interdependence. An ethic of reciprocity also involves the practice of considering the implications of humans' actions, including our research, for all the communities with which humans are in a relationship and on which our existence depends. Beyond the scale of a person, an ethic of reciprocity can also be considered politics; as Leanne Simpson (2017) explains,

Extraction and assimilation go together. Colonialism and capitalism are based on extracting and assimilating. My land is seen as a resource. My relatives in the plant and animal worlds are seen as resources. My culture and knowledge is a resource... The alternative to extractivism is deep reciprocity. It's respect, it's relationship, it's responsibility, and it's local.

(Simpson 2017, 75)

Although Inez remains indifferent to the power of plants and perceives them as passive objects, ultimately, the protagonist of Amadahy's novel recognises her interdependence and the agency of plants, specifically tobacco. Before joining a meeting with representatives of a corporate giant, Inez programmes a nanovirus that would protect her from sexual violence. "I can build a microscopic power source, a self-assembled biogenerator that feeds off the glucose inside my body. (...) We can program the dormant nanovirus to activate when bully circuit lights up within the host body (...) They'll pinch nerves along the spinal column - debilitating pain" (Amadahy 2013, 126). Despite her confidence in the nanovirus, it initially does not work when one 
of the company members, Garen, attempts to rape her. However, the moment Garen reaches into her bra and pulls out the tobacco tie Louise has given her, the nanovirus starts to work. Sexual arousal activates specific neural pathways, and they, in turn, activate the nanobots. It ends with Garen collapsing to the floor again, flailing in pain.

After the return to her community, Inez analyses the situation. It turns out that the "DO NO HARM protocol" has remained in effect the whole time. The nanobots have never downloaded any programming that would have caused pain or harm to a human being. Her scientific worldview does not explain what has activated the nanovirus and turned the "DO NO HARM protocol" off. Several characters want to convince her that it could also be explained with psychokinesis, i.e. the psychic ability allowing a person to influence a physical system without physical interaction. Inez remains sceptical about this idea and considers it a pseudoscience. However, she changes her mind after her second encounter with the company owners. The plan to infect the company members fails again as Scaithwaite and Felipe Gonzales were nanovirus-free. Her former employer wants to rape her. Fortunately, tobacco tie signals the nanovirus into action, which helps her end the conflict with the Scaithwaite. Inez has difficulty comprehending what she witnesses because her scientific paradigm does not explain them. She initially assumes that she has developed the capacity to manipulate a person's biological processes with her intention telekinetically. Nevertheless, she realises that it was the tobacco that activated the nanovirus. Inez changes her opinion, acknowledges the importance of Indigenous knowledge, and tries to connect to the "wisdom in her bones" following Grandma Louise's advice.

The protagonist of Resistance cannot initially comprehend that tobacco in Amadahy's novel exerts influence and great material power; it possesses material agency that makes things happen. Tobacco is not a character whose psychological motivation can be analysed, yet it employs agency just as the humans who interact with it. Inez's cannot understand that tobacco possesses agency, which results from the fact that the notion of the agency has been traditionally linked to intentionality and rationality. It is essential to realise that what humans believe to be agency is not strictly human or intentional. The term does not apply to one thing acting upon or affecting another because it is based upon "an atomistic rather than a congregational understanding" (Bennett 2010, 20). As Jemma Deer explains, agency occurs between things, it is a characteristic of "the dynamic inter-actions of all kinds of forces (human and non-human, conscious and unconscious, organic and inorganic) as they act upon and through each other" (Deer 2021, 13).

Tobacco can also be described, in the words of Jane Bennett, as an "actant," whose efficacy or agency depends on the cooperation or interaction between different bodies and forces. The idea of agency in the novel discussed is reconfigured once non-human things are viewed as actors rather than social constructions, and humans are assessed as "vital materialities" (Bennett 2010, 21). In Bennett's view, plants and humans are formed from the same vital material and actively participate in creating networks of associations. "Vibrant matter" is derived from the monism of the Dutch philosopher Baruch Spinoza, who claims that everything and everyone is composed of the same 
basic building blocks of matter-energy. As Bennett maintains, we - humans and non-humans - are equally responsible for each and every association made between us. There is no subject/object dialectic. It can be illustrated with Latour's anecdote; the scholar notes that when a puppeteer is asked if he controls the marionette, he will respond that the marionette often "asks" him to do things he had not intended. As one of the earliest scholars of the non-human, Arjun Appadurai, states, all things have "lives," "moving through different hands, contexts, and uses" (Appadurai 1986, 13).

The novel illustrates an expanded definition of agency that includes the non-human 'actants' with whom humans co-constitute the world. It seems to reflect the concerns of the new materialists, who seek to depict a vision of the human as situated within a constant flux of material flows that allow for unpredictable occurrences with the agential more-than-human world. Stacy Alaimo's theory of "trans-corporeality" can serve here as an example; it presents bodies as permeable and porous, which are in a state of relationality. The scholar believes that "reconsiderations of materiality... must grapple... with the question of material agency since the evacuation of agency from nature underwrites the transformation of the world into a passive repository of resources for human use," which has resulted in environmental damages (Alaimo 2010,143). It is noteworthy that Alaimo develops here Donna Haraway's argument that "to be one is always to become with many" (Harraway 2008, 4). Transcorporeal becoming points to the plurality of non-human agencies that give voice to the variety of 'things.' Recognising such the entanglement of non-human agencies with which we constantly 'intra-act,' in Karen Barad's words, means a change of our relationship with the world (Barad 2007, 33).

It is noteworthy that many of the aforementioned Euro-Western researchers are often criticised by Indigenous scholars for writing about the entanglements of "nature" and "culture" as if they had "discovered" them. The Métis scholar Zoe Todd (2016), for example, addressed Bruno Latour and his failure to recognise Indigenous thinkers for their "millennia of engagement with sentient environments, with cosmologies that enmesh people into complex relationships between themselves and all relations" (2016, 6). In her 2013 paper, Vanessa Watts, Haudenosaunee and Anishinaabe researcher, criticises, for instance, Bruno Latour and Donna Haraway, for conceptualising non-human agency in a Eurocentric, colonial way (Watts 2013, 21). Instead, Watts proposes a conception of non-human agency that involves what she refers to as Indigenous Place-Thought as well as the distinction between flesh and things, which some Euro-Western scholars made. As Watts claims, this Place-Thought "is based upon the premise that land is alive and thinking, and that humans and non-humans derive agency through the extensions of these thoughts" (Watts 2013,21). Watts suggests that the agency should be perceived as connected to spirit, and "spirit exists in all things, then all things possess agency," rather than referring to the soil as "actants," whose agency is determined by the interactions with humans (ibid. 29-30).

The perception of plants, insects, and Earth as actants by Indigenous people has an ancestral basis. Some traditional Creek stories involve humans talking and chanting to plant beings who, in turn, express themselves aurally through songs, rhythms, 
and forms of direct utterance (Chaudhuri and Chaudhuri 2001, 33). A Mvskoke/Creek writer, Joy Harjo, warns against the intertwined "dehumanisation" of humans and plants by a technocratic force that "flatlines us to think and be in one dimension, or one mind" and which simultaneously reduces the vegetal to a voiceless artefact (Harjo and Winder 2011, 103). In a 2009 interview with Anishinabe scholar Loriene Roy, Harjo describes the consequences of dehumanising plants by denying them a song and disregarding their powers:

\footnotetext{
There are over five hundred indigenous nations and cultures [in the United States], each with helpers. There are established relationships. Plants are beings and require respect and singing if they are to be helpful. We all owe our lives to the helpfulness and sacrifice of plants. Corn is very powerful. Corn has managed to be included as an ingredient in almost every manufactured 'food' item in this country. The impetus of corn therefore is very powerful. If we enslave plants, disrespect them, abuse them, we get the same in return. (Harjo and Winder 2011, 64-65)
}

The manufacturing of corn syrup results in the dehumanisation of corn. For Harjo, the widespread addiction to the industrially processed corn-based sweetener is evidence that "the meaning of corn and our relationship to it gets lost and perverted in the process" (Harjo and Winder 2011, 102). Similarly, tobacco is another example of the modern dehumanisation of a spiritually potent plant. Native Americans consider tobacco to be a sacred and life-affirming persona (Winter 2000, 3). In an article "Dehumanization Flatlines," first published in the Muscogee Nation News in 2007, Harjo discusses the modern maltreatment of tobacco and its transformation into an addictive commodity: "Consider tobacco and how it has served us traditionally. It too has been dehumanised by process, by lack of respect in its use" (Harjo and Winder 2011, 102). In the same interview with Loriene Roy, she refers to tobacco as in need of respect and judicious use: "It is a beloved plant for my people, and is a different plant than used in the manufacture of tobacco products. We used to use it sparingly. It's a powerful plant. The power gets angry when misused" (Harjo and Winder 2011, 65). Indigenous peoples' literature, including Zainab Amadahy's Resistance, thus can be interpreted as a way of restoring respectful relationships with vegetal nature.

\section{Rethinking the notions of life and animism}

In her novel, Amadahy presents tobacco as a living, active agent, challenging the perception of life and nonlife. In this context, it is worth pointing to Elizabeth Povinelli's criticism of the concept of biopower, i.e. a political economy that includes strategies focusing on the regulation of human and non-human life-forms. In Plant Theory: Biopower and Vegetable Life, Jeffrey Nealon illustrates, for instance, how biopower restricts the meaning of life to animal life, excluding plants and other forms from consideration (Nealon 2020). Biopolitically, animals, plants, bacteria, and humans are increasingly 
being organised according to the same kind of the lowest common denominator - utility. In her book Geontologies. A Requiem to Late Liberalism, Elizabeth Povinelli postulates, instead, the transition to geontopower, i.e. the power of and over nonlife, which is concerned with life and nonlife and departs from the distinction between life and death (Povinelli 2016, 4). Following Eduardo Kohn's observations in How Forests Think, Povinelli discusses semiosis, which allows for the distinction between life and nonlife. The scholar notes: "[a]1l living things are like us, if we understand that our dominant mode of semiosis, language, is just one of many kinds of semiosis," thus, communication through language is no longer the standard (Povinelli 2016, 185).

In the "Material ecocritical reflections," Serpil Opperman elaborates on the semiosis as well and links it to the liveliness of the things humans observe and interact with" (Oppermann 2018, 9). These things are described as "alive and undeniably expressive. They have their own stories to tell, showing how nature enacts entanglement... for storying the world is also a process of relation-making" (ibid.). Opperman abolishes the mind/matter dichotomy claiming that "material phenomena are not isolable from semiotic processes and that matter can be creatively expressive in bearing material stories about ecological crises interlaced with socio-political struggles and geophysical forces" (ibid. 10). Oppermann believes that plants, substances, forms of animate and inanimate life possess material agencies; they constantly interact, forming narratives. Zainab Amadahy's novel seems to illustrate this; instead of anthropomorphising plants, the writer presents them as living organisms and allows them to communicate them in their own material way.

In view of the "intertwined" relationships between living and non-living, human and non-human, which become more significant in the Anthropocene, an environmental humanities researcher, Jemma Deer, expresses a need for an ontology that works beyond such distinctions. In her 2021 book, Radical Animism, Deer explains that such a theory is animism, which needs to be rethought. This involves tackling the cultural violence and disregard that has dominated the Western perception of animistic cultures (Deer 2021, 50). The notion of animism has been long applied in the context of primitive belief systems that attribute life, spirit, or soul to the inanimate. This conception has been popularised by the nineteenth-century anthropologist E. B. Tylor, who argued that the animist ontology is founded upon the inability to differentiate between "subjective and objective, between imagination and reality" (Tylor 1871, 402). In African Literature, Animism and Politics, Caroline Rooney notices that animism is considered "a rather unfashionable term because of the ethnocentric, universalising and ill-informed ways in which it has been used. It belongs to the repertoire of terms that have aimed to distinguish between primitive and modern thought" (Rooney 2000, 8). As a result, animism has been substituted by modern science's rationality and objectivity.

In Facing Gaia, Bruno Latour, describes the rejection of animism as a "movement of deanimation":

Although the official philosophy of science takes the... movement of deanimation as the only important and rational one, the opposite is true: animation is the essential phenomenon; 
Pobrane z czasopisma New Horizons in English Studies http://newhorizons.umcs.pl Data: 26/04/2023 15:50:55

Plant Life and More-than-human Agency in Zainab Amadahy's Resistance

and deanimation is the superficial, auxiliary, polemical, and often defensive phenomenon" (Latour 2017, 8-9).

The deanimation of matter in Western scientific tradition reinforces the presumption that the natural environment is passive and that only humans have agency. In the context of global warming, the same scientific paradigm reveals such deanimation to be a "naïve" belief. Scientists claim that human beings should not be seen as separated from 'nature' as it may result in the extinction of our own species. The vitality of matter should not be denied at a time when the planet is responding in numerous ways to the ways humans live. In the face of the crisis, animism gains a new significance; as Tom Cohen claims, "the swarming logics of climate change arrive to deconstruct the artefactual real of human modernity as if from without (though this arrival discloses that there was no "outside" as such)" (Cohen 2010, 74).

Some contemporary scholars promote a more respectful concept of animism in their works, thus, attempting to recognise life and agency beyond the human. These researchers include such researchers as David Abram, Elizabeth Povinelli, Isabelle Stengers, Bruno Latour, Philippe Descola, and Eduardo Viveiros de Castro. They all consider the animist perception of non-human agency to be logically undeniable and question the idea of absolute scientific objectivity. Even though these scholars and other new materialist introduce new terminology, Jemma Deer postulates to use the word 'animism' to talk about non-living and non-human forms of life. Reclaiming the term from its ethnocentric, narrow origin would enable questioning the worldview from which the animist standpoint is discredited. It is noteworthy that this paper does not postulate any type of neoprimitivism or a return to "nature," since, as Timothy Morton (2007) and others have noted, the notion of "Nature" is highly questionable in the context of the Anthropocene. Instead, animism is an effort to recognise the non-living and non-human forms of life and agency.

\section{Conclusion}

To conclude, rather than propagating the vision of the human as the only rational thing, a vision that contributed to the ecological crisis, Zainab Amadahy's Resistance explores the connection between Indigenous people and the non-human environment in ways that emphasise interdependence. The novel illustrates an expanded definition of agency that involves the non-human 'actants' with whom humans co-constitute the world. In contrast to many traditional literary depictions of plants, tobacco possesses material agency; it is an active, living agent, which communicates in its material way. The paper also addresses the disregard that has dominated the Western perception of animistic cultures and expresses the need to rethink the theory of animism. To think animistically indicates the recognition of and the respect for the relational and unintentional forms of agency. 


\section{References}

Alaimo, Stacy. 2010. Bodily Natures: Science, Environment, and the Material Self. Bloomington: Indiana University Press.

Amadahy, Zainab. 2013. Resistance. Toronto, Ontario: CreateSpace Independent Publishing Platform.

Appadurai, Arjun. 1986. The Social Life of Things: Commodities in Cultural Perspective. New York: Cambridge University Press.

Aristotle. 1932. Politics. Translated by Harris Rackham. New York: G. P. Putnam's Sons.

Barad, Karen. 2007. Meeting the Universe Halfway: Quantum Physics and the Entanglement of Matter and Meaning. Durham: Duke University Press.

Bennett, Jane. 2010. Vibrant Matter: A Political Ecology of Things. Durham: Duke University Press.

Bishop, Katherine E., David Higgins, and Jerry Maatta. 2020. Plants in Science Fiction: Speculative Vegetation. Cardiff: University of Wales Press.

Chaudhuri, Jean, and Joyotpaul Chaudhuri. 2001. A Sacred Path: The Way of the Muscogee Creeks. Los Angeles: UCLA American Indian Studies Center.

Clark, Timothy. 2010. "Some Climate Change Ironies: Deconstruction, Environmental Politics and the Closure of Ecocriticism." Oxford Literary Review 32 (1): 131-149. https://doi. org/10.3366/olr.2010.0009

Cohen, Tom. 2010. "The Geomorphic Fold: Anapocalyptics, Changing Climes and 'late' Deconstruction." Oxford Literary Review 32 (1): 71-89. https://doi.org/10.3366/olr.2010.0006

Deer, Jemma. 2021. Radical Animism: Reading for the End of the World. London: Bloomsbury Academic.

Gagliano, Monica, John Ryan, and Patricia Vieira. 2017. The Language of Plants: Science, Philosophy, Literature. Minneapolis: University of Minnesota Press.

Hall, Matthew. 2011. Plants as Persons: A Philosophical Botany. Albany: State University of New York Press.

Hallé, Francis. 2002. In Praise of Plants. Portland, OR: Timber Press.

Haraway, Donna. 2016. Staying with the Trouble: Making Kin in the Chthulucene. Durham: Duke University Press.

Harjo, Joy, and Tanaya Winder. 2011. Soul Talk, Soul Language: Conversations with Joy Harjo. Middletown, CT: Wesleyan University Press.

Harraway, Donna. 2008. When Species Meet. Minneapolis: University of Minnesota Press.

Harris, Dylan M. 2017. "Telling the Story of Climate Change: Geologic Imagination, Praxis, and Policy." Energy Research \& Social Science 31: 179-83. https://doi.org/10.1016/j. erss.2017.05.027

Heidegger, Martin. 2001. The Fundamental Concepts of Metaphysics: World, Finitude, Solitude. Bloomington, Indiana: Indiana University Press.

Justice, Daniel Heath. 2018. Why Indigenous Literatures Matter. Waterloo, Ontario, Canada: Wilfrid Laurier University Press. 
Pobrane z czasopisma New Horizons in English Studies http://newhorizons.umcs.pl Data: 26/04/2023 15:50:55

Plant Life and More-than-human Agency in Zainab Amadahy's Resistance

Kimmerer, Robin Wall. 2013. Braiding Sweetgrass: Indigenous Wisdom, Scientific Knowledge, and the Teachings of Plants. Minneapolis: Milkweed.

Kovach, Margaret. 2009. Indigenous Methodologies: Characteristics, Conversations and Contexts. Toronto, Canada: University of Toronto Press.

Latour, Bruno. 2017. Facing Gaia: Eight Lectures on the New Climate Regime. Cambridge: Polity Press.

Mabey, Richard. 2018. The Cabaret of Plants: Botany and the Imagination. London: Profile Books, Cop.

Morton, Timothy. 2007. Ecology without Nature: Rethinking Environmental Aesthetics. Cambridge, MA: Harvard University Press.

Nealon, Jeffrey T. 2020. Plant Theory: Biopower and Vegetable Life. Plant Theory. Stanford, CA: Stanford University Press.

Oppermann, Serpil. 2018. "The Scale of the Anthropocene: Material Ecocritical Reflections." Mosaic 51 (3): 1-17.

Povinelli, Elizabeth A. 2016. Geontologies: A Requiem to Late Liberalism. Durham: Duke University Press.

Robert Hass. 2005. "The Problem of Describing Trees." The New Yorker. Accessed November 15, 2018. https://www.newyorker.com/magazine/2005/06/27/\%0Athe-problem-of-describing-trees.

Rooney, Caroline. 2000. African Literature, Animism and Politics. London: Routledge.

Simpson, Leann Betasamosake. 2017. As We Have Always Done: Indigenous Freedom through Radical Resistance. Minneapolis, MN: University of Minnesota Press.

Skemp, J. B. 1947. "Plants in Plato's Timaeus." The Classical Quarterly 41 (1-2): 53-60. https://doi.org/10.1017/S0009838800025660

Todd, Zoe. 2016. “An Indigenous Feminist's Take On The Ontological Turn: 'Ontology’ Is Just Another Word For Colonialism.” Journal of Historical Sociology 29 (1): 4-22. https://doi. org/10.1111/johs. 12124

Tylor, Edward Burnett. 1871. Primitive Culture: Researches into the Development of Mythology, Philosophy, Religion, Art, and Custom. Vol. I. London: John Murray.

Wallace-Wells, David. 2019. The Uninhabitable Earth: A Story of the Future. London: Penguin Books Ltd.

Wandersee, James H., and Elisabeth E. Schussler. 1999. "Preventing Plant Blindness." The American Biology Teacher 61 (2): 82-86. https://doi.org/10.2307/4450624

Watts, Vanessa. 2013. "Indigenous Place-Thought and Agency amongst Humans and Non-Humans." Decolonization: Indigeneity, Education \& Society 2 (1): 20-34.

Winter, Joseph. 2000. "Introduction to the North American Tobacco Species." In Tobacco Use by Native North Americans: Sacred Smoke and Silent Killer, edited by Joseph Winter, 3-8. Norman: University of Oklahoma Press. 